\title{
Suicide: A Preventable Phenomenon in Adolescents
}

\author{
Maria Helena de Agrela Gonçalves Jardim ${ }^{1 *}$, Rita Baptista Silva ${ }^{2}$, Geraldo Bezerra da Silva Junior ${ }^{3}$, \\ José Peixoto Caldass ${ }^{4}$ Zélia Santos ${ }^{3}$, Isa Baptista Silva ${ }^{5}$
}

${ }^{1}$ University of Madeira, Funchal, Portugal

${ }^{2}$ Hospital do Funchal, Funchal, Portugal

${ }^{3}$ University of Fortaleza, Fortaleza, Brasil

${ }^{4}$ University of Porto, Porto, Portugal

${ }^{5}$ Hospital of Cascais, Cascais, Portugal

Email: ^hjardim@uma.pt

How to cite this paper: de Agrela Gonçalves Jardim, M. H., Silva, R. B., da Silva Junior, G. B., Caldas, J. P., Santos, Z., \& Silva, I. B. (2017). Suicide: A Preventable Phenomenon in Adolescents. Psychology, 8, 1008- 1018

https://doi.org/10.4236/psych.2017.87066

Received: March 27, 2017

Accepted: May 19, 2017

Published: May 22, 2017

Copyright (c) 2017 by authors and Scientific Research Publishing Inc. This work is licensed under the Creative Commons Attribution International License (CC BY 4.0).

http://creativecommons.org/licenses/by/4.0/

\begin{abstract}
The profound changes in environmental, ecological, socio-cultural, ideological and familiar materials in the last decades, confront adolescents with situations of hostility often generators of mental disorders in particular suicide risk. These evidences advocate the imperious need to promote mental health and balance of individual/social citizens, particularly the younger ones. In this context, the author developed a cross-sectional study, correlational and inferential statistics, whose aim is to "evaluate the level of suicidal risk of young students from 12 to 18 years of the Autonomous Region of Madeira Island (RAM), Portugal". The representative sample is probabilistic and stratified, composed of 1557 adolescents of both genders, attending basic and secondary schools in the municipality of RAM whose average age is 15.2. The selected measuring instrument was the suicide risk scale of Stork which showed high internal consistency (Alfa de Cronbach $=0.91$ ) and good reliability. Most youngsters show no suicidal risk (67.7). However, $16.8 \%$ of young people should be the subject of concern, as $10.1 \%$ reveal weak risk, $4.0 \%$ showed important suicidal risk and $2.7 \%$ suicidal risk is extremely important. There is an association between suicidal risk $(\mathrm{p}=0.000)$ gender and age groups $(\mathrm{p}=$ 0.000 ), being the highest rates in the 15 to 18 age group. As schooling level increases, the risk of suicide, on the basis of the number of failures, being most evident in those that failed once. Parents being married or not also influences the manifestation of suicidal risk $(\mathrm{p}=0.003)$, being most evident in young people whose parents are not married. The fact that the adolescents deal or dealt with some disease $(\mathrm{p}=0.038)$, drink or have drunk alcohol $(\mathrm{p}=0.003)$ as well as not socializing with colleagues $(\mathrm{p}=0.000)$; has significant influence on the suicidal risk. In the same way, taking or have taken drugs $(p=0.000)$
\end{abstract}


influence the suicide risk. These results are a contribution in the statistics field of action. To study the suicide risk is an incentive to the scientific community for future research and the development of strategic support programs with specific interventions to promote the mental health of young people and social and educational policies.

\section{Keywords}

Suicidal Risk, Suicidal Ideation, Suicide, Teens, Adolescents, Crisis, Youths, Suicidal Risk Scale of Stork

\section{Introduction}

Study the risk of suicide requires a tireless pursuit of your motives, just requires a deep reflection about what feelings, faults, failings, secrets or dilemmas they destroy a person in despair. Young people are among the most affected being gradually vulnerable to deviant behaviours. Worldwide, suicide is one of the three leading causes of death in the most economically productive age group (15 44 years) and the second leading cause of death in the age group of 15 to 29 years (Patton et al., 2009).

To analyse the suicidal behaviour need mentioning concepts such as suicide, attempted suicide and suicide attempt (Nabais, 2014). The first is seen as a self-destruct as a result of a premeditated act to achieve this outcome. The second is defined as the act or non-fatal signal of self-harm description itself inaccurate, since the intention to put an end to life, underlying the acts, is difficult to assess. As for the unsuccessful attempts is considered a casual conduct of the individual and, therefore, he expresses no clear purpose to die, the degree of design much lower than the lethal suicide attempt, but with intent to cause damage to himself (more or less), risking to changes, through the real physical consequences or expected (Oliveira et al., 2001; Saraiva, 2010; Gonçalves et al., 2011; Nabais, 2014). Clinical and epidemiological studies suggest the presence of a possible gradient of severity and heterogeneity between the different categories, suicidal ideation, suicide attempts and suicide. In one of the extremes is ideation (thoughts, ideas, planning and desire to kill) and, on the other, the consummate, and suicide attempt among them (Werlang et al., 2005).

The World Health Organization (World Health Organization, 2014a) points as leading causes of death in adolescents traffic accidents, the collective violence and relational, self-harm, AIDS and drowning. In accordance with the mentioned above, in almost all regions of the globe, the suicide (essentially by self-harm) is one of the three leading causes of death in females in the age group of 15 to 19 years of age.

In Portugal, the suicide is responsible annually for more than 1000 deaths and is the cause of premature death more preventable, and having been increasing since the year 2000 (OE, 2012). 
According to data from the National Institute of Statistics (INE, 2015), in recent years the suicide has recorded higher values of deaths by traffic accidents, being among the five leading causes of death in the age group of 15 - 19 years, being the second most common cause of death in the age group of 15 - 29 years (WHO, 2013).

The passage from childhood to adolescence leads to the loss of security in order to be autonomous and occupy a place in the adult world. This is one of the reasons for the teens to be taken as one of the most prone to suicidal behaviour (Bouchard, 2006). In this way it becomes crucial to understand how young people can acquire suicidal behaviours, as well as the factors that influence this act. In fact, a wide variety of risk factors, such as anxiety symptoms, States of depression, substance use, weak family support, friendship issues and stories of abuse may lead to suicidal ideation in adolescents. However, some studies show that certain risk factors are developed because of the impact of the economic crisis in the family, financial and social environment in which the teenager is inserted and claim that the suicide attempts and self-harmful behaviours are the main concerns of public health among teens (Tuisku et al., 2014).

In a comprehensive way, in the genesis of youth suicide, we find root causes, associated with a high degree of suffering can be physical, psychological or socio-cultural origin and scientific evidence shows that factors such as hopelessness, interpersonal skills, social isolation, depression and unemployment, in connection, increase and trigger the suicide. The suicide is seen by young people as a desire to change and/or end up with the problems they experience (Bouchard, 2006).

It should be noted that during adolescence suicide is seen as a tragic phenomenon, which continues to grow. We consider it necessary to implement the prevention of the risk of youth suicide in the programs of the health and teaching professions, as well as to the community, in order to increase the knowledge in the field of dyad adolescence-suicide, aiming at the reduction of this problem.

In the present study we opted for summarize the stages of adolescence in two according to age (Ladame, 2001):

Pre Adolescence (12 to 15 years) in which the adolescent struggle against the dilemma of feelings of loneliness, isolation and regression and the safety that parents constituted;

Adolescence Itself (of 15 to 18 years) period in which the teenager looking for emotional independence in relation to parental and social pairs objects exert a greater importance on empowering thoughts, desires and activities. Depression is one of the most common psychiatric disorders in adolescence in the 21 st century (Levisky, 2002) and interferes significantly in life, social relations and overall well-being, and can lead to limit situations such as the risk of suicide ideation (Oliveira et al., 2001).

The aim of this study is to estimate the level of suicidal risk of young students from 12 to 18 years of the Autonomous Region of Madeira, Portugal. The information produced in this research is innovative, contributing to the develop- 
ment of new research and specific programmes of assistance in promotion of mental health of young people.

\section{Methods}

\subsection{Research Project}

The type of study is quantitative, transversal and inferential statistics.

\subsection{Population}

A representative sample ( $\mathrm{n}=1557$ students) stratified, probabilistic, and of both sexes, by municipality of RAM and grade level (with a sampling error of $1.2 \%$ ).

Inclusion criteria: young people attending normal school, students from the 7th grade level, of 12 to 18 years inclusive, be considered "normal", without psychiatric complaints and which are not under the action of stimulants or depressants of the Central Nervous System.

Exclusion criteria: students with psychiatric treatment, aged below 12 and over 18 years, hat do not meet properly the sociodemographic data questionnaire or the measuring instruments used in this study.

\section{Data Collection Procedures}

All data were collected at the beginning of the school year 2014/2015, from September to December 2014.

Then we inform in good time the directors of the respective school's councils, which had knowledge of the tests, as well as selected classes and sessions' school on schedule the students to the administration of the questionnaires.

The entire administration of the questionnaires was managed by the author of the study.

\subsection{Ethical Issues}

Required prior consent to the Secretariat of Education of Madeira and to the directors of the schools selected.

We respected the confidentiality, anonymity and informed consent not only of the teenagers themselves, but also of the guardians.

\subsection{Instruments}

Characterization survey: sex; age; health; need for medical consultation; age of the parents, educational establishment; grade level; school failure; profession/ occupation of father and mother; composition of the family; consumption of alcohol and drugs; socializing with colleagues and sports.

The Suicidal Risk Scale of J. Stork. This measuring instrument in addition to the possibility of diagnosing the suicidal risk within a range of behaviors, allows, also, a suicidal depressive personality profile and therefore used in determination of the depression, allowing the depression in its two strands, feeling and action. The authors kept the theme of $j$. Stork: loss of subject ( 6 items); anguish (17 items); guilt (8 items); Ideal of himself (15 items); family situation (11 items); 
relationship with his mother (9 items); relationship with the father (4 items); aggression (4 items); addiction (1 item); psychosomatics ( 1 item).The scale was validated for the Portuguese population (Eufrásio et al., 1986).

The scale was reduced to 175 items to 76 , saving, however, your validity. This scale assumes the existence of a relationship between the suicidal act and a depressive type personality or depressive personality profile.

In this sense, the higher the score of the subject on the scale, the greater the probability of the subject have a depressive personality (or depression) and, consequently, the greater the risk suicidal.

This scale, depending on the score obtained by the subject, provides five levels of risk: 0 - 63 Normal State; 64 - 79 Intermediate State or Doubtful; 80 - 97 Weak Risk; 98 - 107 Suicidal Risk Important; above 107 Suicidal Risk is extremely important.

\subsection{Prediction of Statistical Treatment}

Descriptive statistics: frequencies, averages and standard deviation.

Correlational statistics: Cronbach's alpha coefficient and the Pearson correlation coefficient.

Inferential statistics: Student's $\mathrm{T}$ test for comparison of averages and multivariate testing-analysis of variance with Post hoc comparisons (Tukey).

The statistical calculations effected through the IBM SPSS Program 22.

\section{Results/Discussion}

The average age of adolescents is 15.2 years and most are women (55.2\%), as we can see in Table 1 .

Analysing the suicidal risk scale of Stork, notes that the majority of teenagers (67.7\%) expresses a "normal" State (Table 2). Highlights the fact that $16.8 \%$ of young people should be the subject of concern since $10.1 \%$ reveal weak risk, $4.0 \%$ showed important suicidal risk and $2.7 \%$ suicidal risk is extremely important. The observed scores ranged from 2 and 146 points, obtaining an average of 51.49 and standard deviation equal to 27.29. In addition, half of the young people obtained scores equal or smaller to 48.00 and frequency distribution moved away significantly from a normal distribution.

There is significant difference between the suicidal risk and the age group of the adolescent, with $\mathrm{p}=0.000$ (Table 3 ).

The comparison of the average values show that the suicidal risk is higher in older youth, namely at the stage of adolescence itself (of 15 to 18 years), demonstrated that the trend remains since long time. In fact, a decade ago, an investigation (Reinherz et al., 1995) proved that 15 years old is considered critical for

Table 1. Descriptive statistics of the age of the adolescents.

\begin{tabular}{cccccc}
\hline & N. & Minimum & Maximum & Average & SD \\
\hline Age & 1557 & 12 & 18 & 15.20 & 1.78 \\
\hline
\end{tabular}

Note: $\mathrm{SD}=$ standard deviation 
Table 2. Characteristics of the sample in terms of suicidal risk.

\begin{tabular}{ccc}
\hline Rank of suicidal risk & $\mathrm{n}$ & $\%$ \\
\hline "Normal" State & 1054 & 67.7 \\
Intermediate state or doubtful & 241 & 15.5 \\
Weak risk & 158 & 10.1 \\
Suicidal risk important & 62 & 4.0 \\
Suicidal risk is extremely important & 42 & 2.7 \\
& & \\
\hline
\end{tabular}

Table 3. Comparison of suicidal risk depending on the age group and sex of youths.

\begin{tabular}{cccccc}
\hline Suicidal Risk & $\mathrm{n}$ & $\bar{x}$ & $\mathrm{~s}$ & $\mathrm{t}$ & $\mathrm{p}$ \\
\hline Age Group & & & & & \\
{$[12-15]$} & 710 & 47.56 & 26.97 & -5.241 & $\mathbf{0 . 0 0 0}$ \\
{$[15-18]$} & 847 & 54.78 & 27.13 & & \\
Sex & & & & & \\
Male & 698 & 47.95 & 27.24 & -4.638 & $\mathbf{0 . 0 0 0}$ \\
Female & 859 & 54.36 & 27.01 & & \\
\hline
\end{tabular}

the manifestation of suicidal behaviour. In addition, a survey showed that suicidal ideation happens more to 15 years, based on a survey held in Porto Alegre in Brazil (Borges \& Werlang, 2006a).

There is highly significant difference in suicidal risk according to sex $(\mathrm{p}=$ 0.000 ), showing that the young females have a higher predisposition to this disturbance. Accordingly, a study reveals that female adolescents are more prone to grow mental disorders compared to young males (Borges \& Werlang, 2006b). In addition, scientific evidence confirms that girls demonstrate a higher tendency to develop suicidal ideation (Tuisku et al., 2014; Marcus et al., 2012; Correll et al., 2015; Esposito \& Clum, 2002; Hesket et al., 2002).

Note that there is also a significant difference in the number of deprecations young experienced $(\mathrm{p}=0.000)$, being more relevant in that fail only once $(\bar{x}=$ 57.69), according to Table 4. The Tukey test reveals significant differences in terms of suicidal risk occur among teens who never failed and what failed once $(p=0.000)$. A survey (Monteiro, 2013) carried out at the national level, shows that the presence of mental disorders symptoms is strongly associated with the failure and low school performance of young people.

The parents were married or not holds influence in manifestation of mental disorders, given that there are significant differences $(p=0.003)$. The analysis of the average values (Table 5 ) and standard deviations shows us that depression are more patents in young people whose parents are not married $(\bar{x}=55.36$ and $s=28.03$ ). In this perspective, scientists (Stadelmann et al., 2010) emphasizes the failure in marriage or not being married as typical examples of social situations that lead to the suicidal ideation. The family problems and dysfuncmtional families are among the first causes invoked by young suicides (Bouchard, 2006). Similarly, another research (Ferreira, 2008) emphasizes the failure in marriage or not being married as typical examples of social situations that 
Table 4. Comparison of suicidal risk with the number of deprecations at school.

\begin{tabular}{cccccc}
\hline Suicidal Risk & $\mathrm{n}$ & $\bar{x}$ & $\mathrm{~s}$ & $\mathrm{~F}$ & $\mathrm{p}$ \\
\hline Deprecations at school & & & & & \\
None & 1107 & 49.17 & 26.79 & \multirow{2}{*}{14.122} & $\mathbf{0 . 0 0 0}$ \\
One & 257 & 57.69 & 27.26 & & \\
Two and more & 193 & 56.50 & 28.30 & & \\
\hline
\end{tabular}

Table 5. Comparison of depression by the marital status of the parents.

\begin{tabular}{cccccc}
\hline Suicidal Risk & $\mathrm{n}$ & $\bar{x}$ & $\mathrm{~s}$ & $\mathrm{t}$ & $\mathrm{p}$ \\
\hline Marital Status & & & & & \\
Married & 1215 & 50.41 & 27.01 & -2.963 & $\mathbf{0 . 0 0 3}$ \\
Not Married & 340 & 55.36 & 28.03 & & \\
\hline
\end{tabular}

contribute to suicidal risk.

The adolescent who suffer some disease significantly influences the appearance of suicidal ideation $(p=0.000)$. The analysis of the average values of Table 6 , suggests that young people with disease tend to show more pronounced this mental disorder $(\bar{x}=56.86)$. On the other hand, several studies confirm that physical diseases such as cancer, epilepsy, AIDS and some mental disorders (toxic addiction/alcohol and schizophrenia) appear to serious mental disorders in the young, which confirms the data obtained in this study (Correll et al., 2015; Ferreira, 2008). On the other hand, biological factors as existence of chronic diseases and mental disorders, cause the teenager feelings of rebellion and anguish, feeling that life has no meaning, leading to suicidal ideation or suicide itself (Guerreiro, 2014).

The use of drugs and alcohol (Table 7) influences significantly in manifestation of suicidal risk in young people in this study $(\mathrm{p}=0.000 ; \mathrm{p}=0.000)$. Young people who use drugs and alcohol have a higher trend for suicidal ideation (respectively, $\bar{x}=63.93$ e $\mathrm{s}=31.05 ; \quad \bar{x}=61.24$ e $\mathrm{s}=28.42$ ).

These data confirm studies carried out in Brazil (Scheffer et al., 2010; Saide, 2011) showing that individuals who use drugs have a higher predisposition to develop mental disorders, particularly anxiety, depression and suicidal ideation. Accordingly, studies in Rio Grande do Sul (Souza et al., 2010; Almeida \& Scheffer, 2013) reveal that drug use is associated with higher levels of suicidal ideation. Scientific evidence confirms the relationship between alcohol use and suicide (Pompili et al., 2010) and that alcohol abuse may lead to suicidality through disinhibition, impulsiveness and impaired judgment, but it may also be used as a means to ease the distress associated with committing an act of suicide.

The fact that young people do not socializing with the social pairs can be predictor of suicidal risk factors $(\mathrm{p}=0.000)$ in adolescents of Madeira Island, as noted in Table 8. The values of the averages and standard deviations are higher in young people who do not live with colleagues $(\bar{x}=63.31 \mathrm{e} \mathrm{s}=30.57)$. Based on the literature consulted (Pereira, 2011) emphasizes that young people showing signs of loneliness and social rejection exhibit a greater propensity for suicide ideation. Intrinsic to the explanation of suicide emerge youth relationship 
Table 6. Comparison of suicidal risk by health situation.

\begin{tabular}{cccccc}
\hline Suicidal Risk & $\mathrm{n}$ & $\bar{x}$ & $\mathrm{~s}$ & $\mathrm{t}$ & $\mathrm{p}$ \\
\hline Suffering from Disease & & & & & \\
Yes & 372 & 56.86 & 29.61 & 4.380 & $\mathbf{0 . 0 0 0}$ \\
No & 1185 & 49.80 & 26.31 & & \\
\hline
\end{tabular}

Table 7. Comparison of suicidal risk with alcohol and drugs.

\begin{tabular}{cccccc}
\hline Suicidal Risk & $\mathrm{n}$ & $\bar{x}$ & $\mathrm{~s}$ & $\mathrm{t}$ & $\mathrm{p}$ \\
\hline Drugs & & & & & \\
Yes & 72 & 63.93 & 31.05 & 3.502 & $\mathbf{0 . 0 0 0}$ \\
No & 1485 & 50.88 & 26.96 & & \\
Alcohol & & & & & \\
Yes & 148 & 61.24 & 28.42 & 4.598 & $\mathbf{0 . 0 0 0}$ \\
No & 1409 & 50.46 & 26.97 & & \\
\hline
\end{tabular}

Table 8. Comparison of suicidal risk with socializing with colleagues and sports.

\begin{tabular}{cccccc}
\hline Suicidal Risk & $\mathrm{n}$ & $\bar{x}$ & $\mathrm{~s}$ & $\mathrm{t}$ & $\mathrm{p}$ \\
\hline Colleagues Socializing & & & & & \\
Yes & 1489 & 50.95 & 27.02 & -3.668 & 0.000 \\
No & 68 & 63.31 & 30.57 & & \\
\hline
\end{tabular}

difficulties with her parents and friends, and may cause to suicidal behaviour (Guerreiro, 2014). Effectively, have no friends can contribute to suicide, however to establish relations of friendship reveals an important emotional and instrumental support preventive suicide act.

\section{Conclusion}

Suicide is an increasingly important social phenomenon that must be faced in all societies around the world. The suicide prevention, according to the World Health Organization (World Health Organization, 2014b) is a global imperative and, currently, considered as a priority in the European Union (Whalbeck \& Mäkinen, 2008). At the same time, the scientific data show us that many deaths are preventable, but Governments and Regulators do not prioritize the prevention of suicidal ideation.

Effectively prevent the risk of suicide assumes the existence of correct and reliable records of cases, in order to improve the availability and quality of data on suicides and suicide attempts, which is not easy in our collective who still see this issue as a stigma, shame and even taboo.

All the measures of prevention of suicide and acts of deviant behaviours in adolescents must consider not only their particular characteristics, but also, that many young people with these behaviours don't access to mental health care, being detected frequently in schools or in the judicial system.

The regulators and the Health and Education Ministries and respective Regional Secretariats play an integral role, coordinating this process, through a 
solid leadership to ensure well-defined targets and measurable goals (World Health Organization, 2014a; Guerreiro, 2014).

It is necessary to strengthen the support networks of adolescents, involving mainly the family, colleagues and school, promoting more satisfactory relations and greater well-being, considering that the personal relationships they occupy an important role in this stage of the life cycle.

The psychological characteristics of adolescents require that the educational institutions, as well as the family, construct the ideal space where young can progress with health and protection. The school, in particular, the classroom should be privileged spaces in which the troubles of adolescents can be minimized and the increase of knowledge is a tool for growth, development and ownership of healthy lifestyle behaviours, discussion of themes and consolidation of appropriate conduct at school and within the family.

This inferential analysis corroborates the results obtained in numerous studies that teen suicide is a complex phenomenon, in which biological order, psychological factors, sociodemographic and cultural interact with each other and alert to the need to focus on prevention and health promotion of adolescents who expressed vulnerability in appearance of this mental disorder, which in the future will cause dramatic outcomes in adult life.

Against this background, it is necessary to rethink the true meaning that life holds for each and your community, never neglecting the socio-cultural and spiritual values, respecting the integration and social cohesion in a globalising world. Future research should be implemented, adding other important variables in the explanation of these emerging phenomena in society.

\section{References}

Almeida, R. M. M., Flores, A. C. S., \& Scheffer, M. (2013). Ideação Suicida, Resolução de Problemas, Expressão de Raiva e Impulsividade em Dependentes de Substâncias Psicoativas. Psicologia: Reflexão e Crítica, 26, 1-9. https://doi.org/10.1590/s0102-79722013000100001

Borges, V., \& Werlang, B. (2006a). Estudo de ideação suicida em adolescentes de 13 e 19 anos. Psicologia, Saúde \& Doenças, 7, 195-209.

Borges, V., \& Werlang, B. (2006b). Estudo de ideação suicida em adolescentes de 15 e 19 anos. Estudos de Psicologia, 11, 345-351.

https://doi.org/10.1590/s1413-294x2006000300012

Bouchard, G. (2006). Suicídio na adolescência. http://www.projetocomviver.org.br/Suicidio_na_adolescencia.pdf

Correll, C. U., Detraux, J., De Lepeleire, J., \& De Hert, M. (2015). Effects of Antipsychotics, Antidepressants and Mood Stabilizers on Risk for Physical Diseases in People with Schizophrenia, Depression and Bipolar Disorder. World Psychiatry, 14, 119-136. https://doi.org/10.1002/wps.20204

Esposito, C. L., \& Clum, G. A. (2002). Psychiatric Symptoms and Their Relationship to Suicidal Ideation in a High-Risk Adolescent Community Sample. Journal of the American Academy of Child and Adolescent Psychiatry, 41, 44-51. https://doi.org/10.1097/00004583-200201000-00010

Eufrásio, M., Fernandes, O. M., Lopes, I. C., Reis, A. R., \& Dias, C. A (1986). Adaptação 
da Escala de Risco Suicidário de J. Stork para a População Portuguesa. Coimbra: Faculdade de Psicologia e Ciências da Educação da Universidade de Coimbra.

Ferreira, R. (2008). O Suicídio. Trabalho de Licenciatura em Sociologia. Coimbra: Faculdade de Economia da Universidade de Coimbra.

Gonçalves A., Freitas, P., \& Sequeira, C. (2011). Comportamentos Suicidários em Estudantes do Ensino Superior: Fatores de Risco e de Proteção. Millenium, 40, 149-159.

Guerreiro, D. (2014). Comportamentos autolesivos em adolescentes. Características epidemiológicas e análise de fatores psicopatológicos, temperamento afetivo e estratégias de coping. Dissertação de doutoramento Medicina, Especialidade de Psiquiatria e Saúde Mental, Lisboa: Faculdade de medicina de Lisboa.

Hesket, T., Ding, Q. J., \& Jenkins, R. (2002). Suicide Ideation in Chinese Adolescents. Social Psychiatry and Psychiatric Epidemiology, 37, 230-235. https://doi.org/10.1007/s00127-002-0536-9

Instituto Nacional de Estatística, INE (2015). Revista de Estudos Demográficos, (54). Portugal: INE.

Ladame, F. (2001). ¿Para qué una identidad? O el embrollo de las identificaciones y de su reorganización en la adolescencia. Revista de Psicoanalisis APdeBA, XXIII (2).

Levisky, D. L. (2002). Depressões narcísicas na adolescência e o impacto da cultura. Psychê, 6, 125-136.

Marcus, M., Yasamy, T. M., Ommeren, M., Chisholm, D., \& Saxe, S. (2012). Depression: A Global Public Health Concern. WHO, Department of Mental Health and Substance Abuse.

Monteiro, J. P. N. (2013). Depressão e Ideação Suicida em Adolescentes: As várias faces da institucionalização. Vila Real: Universidade de Trás-os-Montes e Alto Douro.

Nabais, L. (2014). Comportamentos de risco em adolescentes e jovens adultos da região de Lisboa. Tese de Doutoramento, Lisboa: Universidade Aberta.

Oliveira, A., Amâncio, L., \& Sampaio, D. (2001). Arriscar morrer para sobreviver: Olhar sobre o suicídio adolescente. Análise Psicológica, 4, 509-520.

Ordem dos Enfermeiros, OE (2012). Guia Orientador de Boas Práticas para a Prevenção de Sintomatologia Depressiva e Comportamentos da Esfera Suicidária. Cadernos $O E$, 4(1).

Patton, G. C., Coffey, C., Sawyer, S. M., Viner, R. M. et al. (2009). Global Patterns of Mortality in Young People: A Systematic Analysis of Population Health. The Lancet, 374, 881-892. https://doi.org/10.1016/S0140-6736(09)60741-8

Pereira, A. (2011). Ideação suicida e fatores associados: Estudo realizado numa amostra da população universitária da Universidade de Trás-os-Montes e Alto Douro. Dissertação de Mestrado em Psicologia, Vila Real. UTAD.

Pompili, M., Serafini, G., Innamorati, M., Dominici, G., Ferracuti, S., Kotzalidis, G. D. et al. (2010). Suicidal Behavior and Alcohol Abuse. International Journal of Environmental Research and Public Health, 7, 1392-1431. https://doi.org/10.3390/ijerph7041392

Reinherz, H. Z., Giaconia, R. M., Silverman, A. B., Friedman, A., Parkis, B., Cohen, E. et al. (1995). Early Psychosocial Risks for Adolescent Suicidal Ideation and Attempts. Journal of the American Academy of Child and Adolescent Psychiatry, 34, 599-611. https://doi.org/10.1097/00004583-199505000-00012

Saide, O. (2011). Depressão e uso de drogas. Revista Hospital Universitário Pedro Ernesto, 10, 47-60.

Saraiva, C. (2010). Suicídio: De Durkeim a Shneidman, do determinismo social à dor 
psicológica individual. Psiquiatria Clínica, 31, 185-205.

Scheffer, M., Pasa, G., \& Almeida, R. (2010). Dependência de álcool, cocaína e crack e transtornos psiquiátricos. Psicologia: Teoria e Pesquisa, 26, 533-541. https://doi.org/10.1590/s0102-37722010000300016

Souza, L. D. M., Ores, L., Oliveira, G. T., Cruzeiro, A. L. S., Silva, R. A., Pinheiro, R. T., \& Horta, B. L. (2010). Ideação suicida na adolescência: Prevalência e fatores associados. Jornal Brasileiro de Psiquiatria, 59, 286. https://doi.org/10.1590/S0047-20852010000400004

Stadelmann, S., Perren, S., Groeben, M., \& Klitzing, K. (2010). Parental Separation and Children's Behavioral/Emotional Problems: The Impact of Parental Representations and Family Conflict. Family Process, 49, 92-108. https://doi.org/10.1111/j.1545-5300.2010.01310.x

Tuisku, V. et al. (2014). Depressed Adolescents as Young Adults-Predictors of Suicide Attempt and Non-Suicidal Self-Injury during 8-Year Follow-Up. Journal of Affective Disorders, 152-154, 313-319. https://doi.org/10.1016/j.jad.2013.09.031

Werlang, B., Borges, V., \& Fensterseifer, L. (2005). Fatores de risco ou proteção para a presença de ideação suicida na adolescência. Revista Interamericana de Psicologia, 39, 259-266.

Whalbeck, K., \& Mäkinen, M. (2008). Prevention of Depression and Suicide. Consensus Paper, Luxembourg: European Communities.

World Health Organization (2013). Mental Health Action Plan 2013-2020. Geneva: WHO.

World Health Organization (2014a). Health for the World's Adolescents: A Second Chance in the Second Decade. Geneva: Department of Child and Adolescent Health Development

World Health Organization (2014b). Preventing Suicide: A Global Imperative. Geneva: WHO.

\section{Submit or recommend next manuscript to SCIRP and we will provide best service for you:}

Accepting pre-submission inquiries through Email, Facebook, LinkedIn, Twitter, etc. A wide selection of journals (inclusive of 9 subjects, more than 200 journals) Providing 24-hour high-quality service User-friendly online submission system Fair and swift peer-review system Efficient typesetting and proofreading procedure Display of the result of downloads and visits, as well as the number of cited articles Maximum dissemination of your research work

Submit your manuscript at: http://papersubmission.scirp.org/

Or contact psych@scirp.org 